\title{
A zoophile's testament
}

The Moral Status of Animals. By Stephen R. L. Clarke. Pp. 221. (Oxford University : Oxford and London, 1977.) $£ 5.95$.

IN fairness to the author of this book, it must be said that he is a professional philosopher and this reviewer is not. And in fairness to this reviewer it must be said that the book is not addressed to philosophers but to the public at large. Moreover, it is not written to inform : it is written to persuade, with an uncompromising vehemence unusual among philosophers. So Dr Clark has to put up with the fact that I'm not competent to comment on the subtleties of his logic, just as I have to put up with Dr Clark's assertion (p183) "that no-one has any standing" in discussing the theme of his book "who has not taken the simple, minimal step of abandoning flesh-foods."

For that is the demand-and 'demand' is not too strong a wordwhich Dr Clark makes upon the reader. "I am a committed crank and zoophile, and my hope is to convert my audience." "Those who still eat flesh when they could do otherwise have no claim to be serious moralists." Dr Clark is fully aware of the consequences which would follow if his mission were to succeed. There would be a phasing out of all animal husbandry, from sheep and poultry, to fisheries and (presumably) shellfish beds. The sight of sheep placidly grazing is offensive to Dr Clark; they are the innocent and unaware "inmates of our Belsens" ( $p 80$ ). If this seems immoderate and emotive language from the pen of a philosopher, Dr Clark defends himself with the statement: "I am very much more interested in achieving a practical issue than in the details of abstract philosophy, and am willing to argue on almost any basis to achieve that end." But even this defence does not excuse such nonsense as the assertion (p188) that "flesh-eaters pretend that their victims delight to serve them."

of course, abstinence from all flesh foods is only one of the demands which Dr Clark makes upon us. There must also be abstinence from all vivisection and from the use of animals to test drugs, on the ground that we must not do to animals anything which we would not legitimately do to human beings.
The book is written in a learned, not to say pedantic style, with copious references to authorities from Porphyry in the third century AD to Roszak in the twentieth century. Dr Clark professes himself to be a Christian but he confesses to finding little support for his thesis in the Bible and he is embarrassed by Christ's participation in the catching of fish. $\mathrm{He}$ admits that there is some sort of hierarchy among living creatures-to murder a sheep is "perhaps in less degree" serious than to murder a shepherd-and he is evasive about insects, although he admits with reluctance (p82) that insects killed on impact with a car windscreen weigh "less heavily than a deliberate killing."

There is an appendix with advice on vegetarian cooking.

This is a deeply disappointing book, for the issues which Dr Clark discusses are important. A critical examination of them would be timely becausecontrary to numerous reckless assertions in Dr Clark's book- the common man is aware as never before of his kinship with the rest of nature. No-one who has seen nature films on TV believes (as Dr Clark implies on p37) that animals are stupid; no-one doubts that they suffer pain, can be apprehensive of danger, and that many kinds of animals are capable of affection, not only within their species but oven toward man.

The widespread empathy between human beings and the rest of the natural world creates an interest in the rights of animals. A careful and sober enquiry into the consequences of this empathy would be welcome. Any such enquiry would have to take into account three considerations, none of which Dr Clark has faced squarely.

First, if as Dr Clark admits, the intensity of concern diminishes as one passes from mammals to vertebrate and from vertebrates to insects, where does it stop? And if not at insects, why not include plants? (Christopher Stone has already written an essay, far more persuasive than Dr Clark's, on the question whether trees should have standing in the law-courts of America.)

Secondly, Dr Clark admits that it's not our business to save the rabbit from the fox or the fly from the spider, but he does not explain why man, as an integral unit in nature, should abdicate from the place he has occupied in the food chain for millennia. Hamlet's "We fat all creatures else to fat us and we fat ourselves for maggots . .." is a curt but accurate summary of man's place in the biosphere.

Finally, much of Dr Clark's case rests on the premise that man must not treat animals with less concern than he treats his fellow men. In fact man treats animals with more concern: we may kill domesticated animals in order to eat them; we don't torture them because they do not share our political or religious ideologies. The intraspecific behaviour of animals to one another is, by and large, more compassionate than our own intraspecific behaviour.

Eric Ashby (Lord Ashby of Brandon) is Walgreen Professor of Human Understanding at the University of Michigan.

\section{Cell surface in embryogenesis}

Cell Surface Reviews. Volume 1: The Cell Surface in Animal Embryogenesis and Development. Edited by George Poste and Garth L. Nicholson. Pp. 766. (North-Holland: Amsterdam, New York and Oxford, 1977.) \$89.95; Dfl.220.

THIS is the first in a new series of volumes designed to collate literature on cell membrane research. Three more volumes (Virus Infection and the Cell Surface, Dynamic Aspects of Cell Surface Organisation, Membrane As- sembly and Turnover) are promised within the year. After this, volumes will be added to the series annually. This book deals with the more general aspects of development.

The chapter by Trinkaus is a scholarly survey of cell movement. Widely held misconceptions are exposed and corrected. Arnold's review on cytokinesis is concise and lucid.

Cell communication is discussed in four of the reviews. Sheridan provides circumstantial evidence for gap junctions as a structural basis for low 